\title{
Anti-tumor efficacy of oncolytic reovirus against gastrointestinal stromal tumor cells
}

\author{
Yusuke Inagaki ${ }^{1}$ Eiji Kubota ${ }^{1}$, Yoshinori Mori², Mineyoshi Aoyama ${ }^{3}$, Hiromi \\ Kataoka $^{1}$, Randal N. Johnston ${ }^{4}$ and Takashi Joh ${ }^{1}$ \\ ${ }^{1}$ Department of Gastroenterology and Metabolism, Nagoya City University Graduate School of Medical Sciences, Mizuho-Ku, \\ Nagoya, Japan \\ ${ }^{2}$ Department of Gastroenterology, Nagoya City West Medical Center, Kita-Ku, Nagoya, Japan \\ ${ }^{3}$ Department of Pathobiology, Nagoya City University Graduate School of Pharmaceutical Sciences, Mizuho-Ku, Nagoya, \\ Japan \\ ${ }^{4}$ Department of Biochemistry and Molecular Biology, University of Calgary, Calgary, Alberta, Canada \\ Correspondence to: Eiji Kubota, email: ekubota@med.nagoya-cu.ac.jp \\ Keywords: reovirus; gastrointestinal stromal tumor (GIST); imatinib; fas; apoptosis \\ Received: August 09, $2017 \quad$ Accepted: December 03, $2017 \quad$ Published: December 18, 2017 \\ Copyright: Inagaki et al. This is an open-access article distributed under the terms of the Creative Commons Attribution License \\ 3.0 (CC BY 3.0), which permits unrestricted use, distribution, and reproduction in any medium, provided the original author and \\ source are credited.
}

\section{ABSTRACT}

Imatinib, a multitargeted receptor tyrosine kinase inhibitor, is used as the standard initial therapy against inoperable gastrointestinal stromal tumor (GIST). However, GIST can acquire resistance to imatinib within several years of therapy. The development of oncolytic reovirus as an anticancer agent has expanded to many clinical trials for various tumors. Here, we investigated whether reovirus has antitumor activity against GIST cells in the setting of imatinib sensitivity in vitro and in vivo. Cell proliferation and apoptosis assays were performed using a human GIST cell line, GIST-T1, and imatinib-resistant GIST (GIST-IR) cells that we established. The molecular pathways responsible for cell damage by reovirus were explored using PCR-arrays and Western blots. Reovirus significantly induced apoptotic cell death in GIST-T1 and GIST-IR cells in vitro, despite differences in the activation of receptor tyrosine kinase pathways between GIST-T1 and GIST-IR. Molecular assays indicated the possibility that reovirus induces apoptotic cell death via Fas signaling. Furthermore, in vivo mouse tumor xenograft models demonstrated a significant antitumor effect of reovirus on both GIST-T1 and GIST-IR cells. Our results demonstrate the therapeutic potential of reovirus against GIST.

\section{INTRODUCTION}

Gastrointestinal stromal tumor (GIST) is the most common mesenchymal neoplasm of the digestive tract. GISTs are believed to originate from interstitial cells of Cajal (pacemaker cells of the digestive tract) or related stem cells, and are characterized by proto-oncogene receptor tyrosine kinase KIT or platelet-derived growth factor receptor alpha (PDGFRA) activating mutations $[1,2]$. Activating mutations of KIT and PDGFRA genes permit ligand-independent phosphorylation of the receptor tyrosine kinase (RTK), perpetuating receptor- initiated signals and causing activation of downstream effectors. Increases in cellular proliferation and decreases in apoptosis lead to the development of neoplasia and enhance cell survival [2]. Imatinib mesylate, a tyrosine kinase inhibitor of KIT and PDGFRA receptors, is the first-line standard therapy for inoperable, metastatic, or recurrent GIST [2]. Although imatinib has been shown to improve survival in patients with GIST, drug resistance in GIST limits the effectiveness of imatinib. Approximately $5 \%$ of patients show primary resistance to imatinib and approximately $14 \%$ of patients develop early resistance; moreover, secondary resistance develops 
after a median of about 2 years of treatment with the drug $[3,4]$. Resistance against imatinib can develop through various mechanisms, and mainly occurs due to additional kinase domain mutations [2, 5]. Sunitinib malate, a multitargeted receptor tyrosine kinase inhibitor, is used as a second-line standard therapy for imatinib-resistant GIST. Although sunitinib has clinical benefits including disease control and superior survival for imatinib-resistant GIST patients, it is ineffective for a cohort of imatinibresistant GIST [4, 6]. Regorafenib, another multitargeted inhibitor, was recently approved as a third-line therapy, but shows limited efficacy [7]. Furthermore, sunitinib and regorafenib have higher rates of adverse events including hand-foot syndrome, diarrhea and hypertension [4, 7]. Therefore, it is necessary to elucidate new therapies and approaches for imatinib-resistant GIST.

Human oncolytic reovirus is a non-enveloped double-stranded RNA virus composed of an outer and inner protein shell, which altogether forms a 20-sided icosahedral capsid [8, 9]. Reovirus preferentially infects and kills transformed cancerous cells rather than healthy normal cells [10]. Though activation of the oncogenic Ras signaling pathway enhances reoviral oncolytic targeting in various types of human cancers, the mechanism of oncolysis by reovirus remains largely unknown [9-12]. The ability of reovirus to infect and lyse tumor cells under in vitro and in vivo conditions has been reported previously [13-16], and clinical trials involving various cancers are underway in the US, the UK, Belgium, and Canada. Several phase I/II clinical trials have demonstrated the safety of reovirus and its successful decrease of tumor size, leading to several phase II/III trials that are now ongoing [9, 16-18]. Despite many successes in translational studies and clinical trials of reovirus therapy against cancers, the efficacy of reovirus against GIST has not been reported to date.

In the current study, we investigated the antitumor activity of reovirus against GIST and imatinib-resistant GIST (GIST-IR), via modulating cell proliferation and apoptosis signaling in vitro, and whether mouse tumor xenograft models could demonstrate the anti-tumor effect of reovirus on GIST cells in vivo.

\section{RESULTS}

\section{Characteristics of GIST-IR cells, imatinib- resistant GIST cells}

We initially characterized the parental cell line, GIST-T1, and the imatinib-resistant cell line, GISTIR. The GIST-IR cells appear spindle-shaped, very similar to the parental cell line, GIST-T1 (Figure 1A). The proliferation of GIST-IR cells was slower than that of GIST-T1 cells (Supplementary Figure 2). To assess the level of GIST-IR cellular resistance to imatinib, we determined the 50\% growth inhibitory concentrations (IC50) for GIST-T1 and GIST-IR cells. Figure 1B shows that the IC50 of imatinib against GIST-T1 was $230 \pm 40$ $\mathrm{nM}$ and the IC50 of imatinib against GIST-IR was $2800 \pm$ $470 \mathrm{nM}$, approximately twelve times higher than for the parental cell line. Secondary resistance to imatinib often develops due to secondary KIT or PDGFRA mutations that interfere with drug binding [2, 11, 19-21]. Most secondary KIT mutations represent single nucleotide substitutions affecting codons in exons 13, 14, 17 and 18 [2, 11, 19-21]. We performed targeted genome sequencing to examine whether GIST-IR cells have mutations that could contribute to drug resistance (Table 1), and did not find any of these gene mutations (data not shown). To analyze the resistant mechanism of GIST-IR cells against imatinib, we investigated differences in protein kinase activations between GIST-IR cells before and after treatment with imatinib, using a RTK phosphorylation array (Supplementary Figure 1). Results for the quantification of RTK phosphorylation array images are shown in Figure 1C. GIST-T1 cells phosphorylated c-Kit, Tie2, VEGFR2, AKT and ERK1/2, and their phosphorylation was inhibited in an imatinib concentration-dependent manner. In GIST-IR cells, several tyrosine kinase receptors and their downstream targets, including c-Kit, VEGFR2, Tie2, AKT, and ERK1/2 were strongly phosphorylated when compared with GIST-T1. In addition, the phosphorylation of these protein kinases did not decrease even in GIST-IR cells exposed to high imatinib concentrations. To ascertain the results of RTK phosphorylation array, we performed western blot and found that imatinib inhibited the phosphorylation of c-Kit, AKT, and ERK1/2 in GIST-T1 in a concentration dependent manner. In contrast, the phosphorylation of these protein kinases was not inhibited sufficiently in GIST-IR even though cells were exposed to high concentration of imatinib (Figure 1D).

\section{Cytotoxic effect of reovirus against GIST cells in vitro}

We evaluated the cytotoxicity of reovirus against GIST-T1 and GIST-IR cells. After treatment with reovirus for five days, cell proliferation decreased significantly in both GIST-T1 and GIST-IR cells in a virus concentrationdependent manner (Figure 2A). Caspase 3/7 activities of cells treated with reovirus were higher than those of the control at all time points $(\mathrm{p}<0.01)$ (Figure $2 \mathrm{~B})$. Moreover, caspase inhibitors including BID inhibitor and caspase 3/7 inhibitor significantly suppressed the caspase $3 / 7$ activities induced by reovirus treatment in both GIST-T1 and GISTIR (Supplementary Figure 3). In accordance with the results of the caspase assays, Western blots showed that reovirus induced both activation of caspase- 3 and PARP cleavage in GIST-T1 and GIST-IR cells after reovirus treatment (Figure 3). 
A

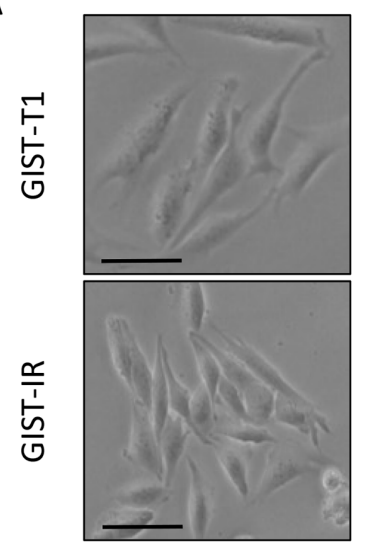

Scale bars $=10 \mu \mathrm{m}$

C<smiles>[SiH2][SiH2][AsH]</smiles>

B

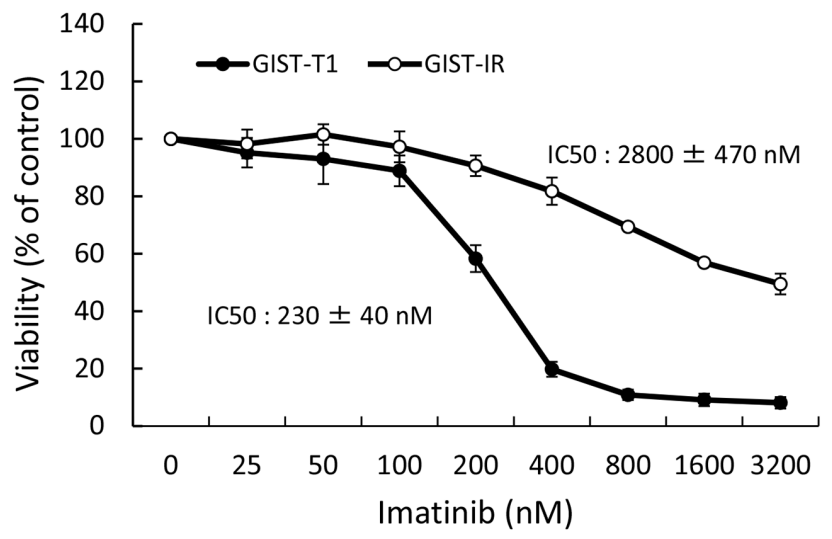

GIST-IR
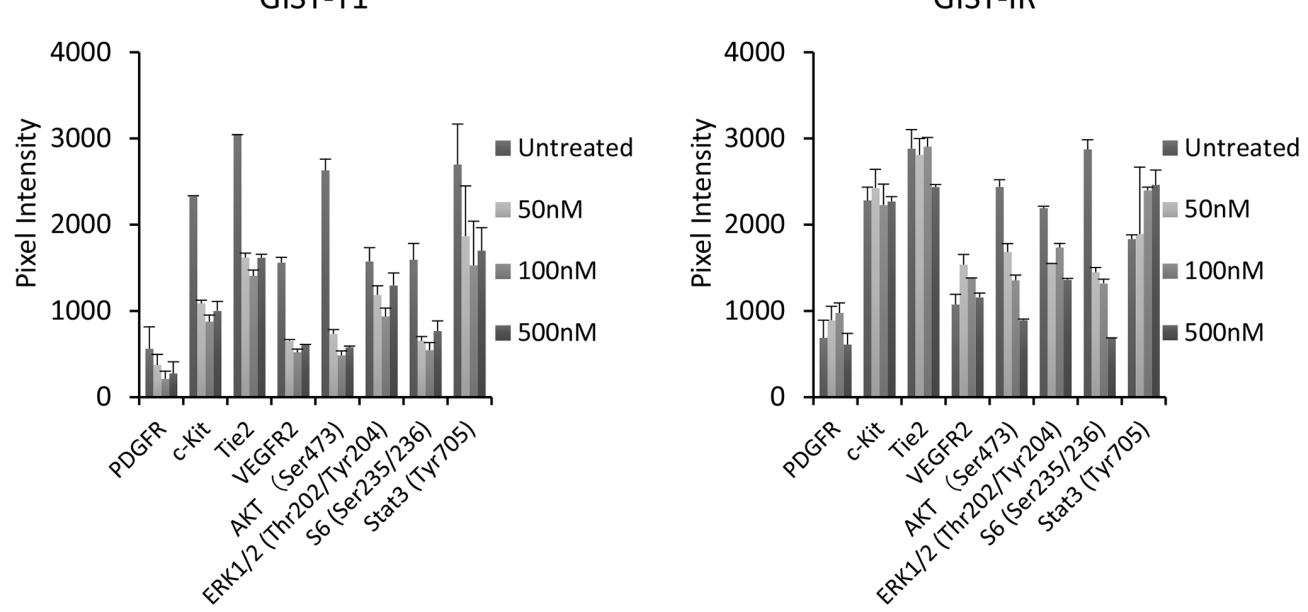

D

GIST-T1

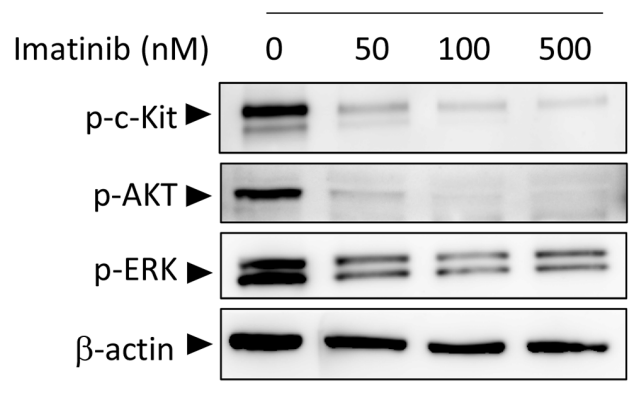

GIST-IR

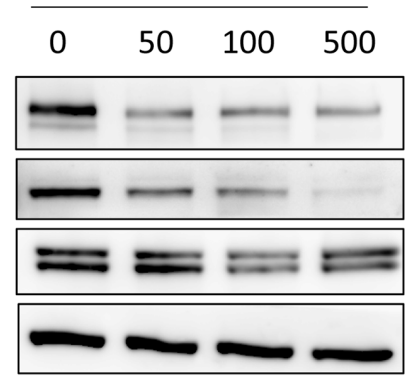

Figure 1: Characterization of the imatinib-resistant GIST cell line, GIST-IR. (A) The appearance of imatinib-resistant GIST cells, GIST-IR cells, shows a spindle-like shape without obvious morphological changes from the parental cell, GIST-T1 cells. (B) $5.0 \times$ $10^{3}$ GIST-T1 or GIST-IR cells were plated in 96-well plates and cultured with imatinib (25 - $\left.3200 \mathrm{nM}\right)$. After 48 hours, cell viability was measured by WST- 8 assay. Imatinib showed efficacy against GIST-T1 and GIST-IR cells with IC50s of $230 \pm 40 \mathrm{nM}$ and $2800 \pm 470 \mathrm{nM}$, respectively. (C) Expression of activated tyrosine kinase receptors and downstream signals in GIST-T1 and GIST-IR cells, and the effect of imatinib on their phosphorylation status were evaluated using RTK signaling antibody array. Bar graphs represent the quantified receptor tyrosine kinase (RTK) signaling antibody array images. Results represent the mean \pm SD of three experiments performed in triplicate. (D) Protein extract from GIST-T1 and GIST-IR cells incubated in culture media supplemented with the indicated concentration of imatinib for 48 hours was immunoblotted with anti-c-Kit (Tyr719), anti-phospho-AKT (Ser473), anti-phospho-ERK1/2 (Thr202/Tyr204). $\beta$-actin is shown as a loading control. 
Table 1: PCR primer sets for the analysis of KIT and PDGFRA mutations contributing to secondary imatinib resistance

\begin{tabular}{llc}
\hline Target & Direction & Primer \\
\hline KIT 13 & Forward & 5'-ACCACCAGCACCATCACCACTTACCTTGTTGTCTT \\
& Reverse & 5'-TTCTGCAAACATCACAGACATCCTTGATGGGAACT \\
KIT 14 & Forward & 5'-TTGGGACTAAGTAGTCTGATCCACTGAAGCTGAA \\
& Reverse & 5'-TATACAGGAATAATCCAGAGGTCGATGGCAAGAA \\
KIT 17 & Forward & 5'-TGCAAAGGCATATTAGGAACTCTGTGAAAGGA \\
& Reverse & 5'-AAATTTCTCCTGCTGTGACCTTCAATGACCTA \\
KIT 18 & Forward & 5'-GTTATCACTCCACATTTCAGCAACAGCAGCATCTA \\
& Reverse & 5'-TCATTATGTCATACCTGCAAGACAAGGGCCATTTA \\
PDGFRA 18 & Forward & 5'-TCTTTGGGCATGCCTCTGCAACCTGATGATTTC \\
& Reverse & 5'-GTGGAGCTGGCACTCAAACCTGGGCAATCTG \\
\hline
\end{tabular}

\section{Molecular response after reovirus treatment in GIST cells}

To understand the molecular mechanisms responsible for apoptosis induced by reovirus in GIST cells, we measured gene expression in GIST-T1 cells treated with reovirus, using a human polymerase chain reaction (PCR) array consisting of 84 apoptosis-related genes. In GIST-T1 cells with reovirus treatment, several apoptosis-related genes showed higher mRNA levels than those in GIST-T1 cells without reovirus treatment (Table 2). Among these candidate genes that account for apoptosis caused by reovirus in GIST-T1 cells, we focused on two apoptosis-related genes, TNF-related apoptosis-inducing ligand (TRAIL) and Fas. TRAIL is known as one of the key factors promoting apoptosis induced by reovirus [22, 23], and we previously reported that the apoptosis-signaling pathway stimulated by TRAIL plays a crucial role in the cytotoxic effect of reovirus against gastric cancer [22]. Furthermore, we investigated the role of Fas in reovirusinduced cell death. Rikhof et al. reported the efficacy of Fas ligand (FasL) against GIST was independent of imatinib sensitivity, and proposed the utility of Fas, which is expressed abundantly in GIST samples, as a potential therapeutic target for GIST [24]. Western blotting analysis demonstrated that TRAIL and Fas were expressed in GIST-T1 and GIST-IR cells, and their expression levels were increased after reovirus treatment (Figure 3A, 3B). Fas protein expression levels were significantly increased, whereas no significant changes were seen in DR4 and DR5 expression after reovirus treatment in either GIST-T1 or GIST-IR cells (Figure 3A).

\section{Role of Fas-FasL pathway in reovirus-induced apoptosis in GIST cells}

To investigate whether TRAIL and FasL are implicated in reovirus-induced apoptosis, we evaluated caspase 3/7 activity and cell viability in GIST-T1 and GIST-IR cells after treatment with TRAIL alone, FasL alone, TRAIL in combination with reovirus, or FasL in combination with reovirus. TRAIL alone did not cause any damage to either GIST-T1 or GIST-IR cells, whereas TRAIL alone induced apoptosis in MKN28, a gastric cancer cell line that expresses abundant DR5 (data not shown here). In contrast, FasL significantly induced apoptosis and suppressed cell viability in both GIST-T1 and GIST-IR cells (Figure 4A). Furthermore, the combination treatment with reovirus and FasL enhanced caspase $3 / 7$ activities and showed the ability to inhibit cell growth in both GIST-T1 and GIST-IR cells. On the other hand, TRAIL did not enhance caspase 3/7 activities in GIST-T1 or GIST-IR cells treated with reovirus (Figure 4B, 4C).

\section{Effect of reovirus on growth of GIST-T1 and GIST-IR cells in vivo}

We examined whether reovirus treatment could efficiently inhibit tumor growth of GIST-T1 and GISTIR cells using a xenograft mouse model in vivo. First, we confirmed that tumors derived from GIST-IR cells displayed resistance to imatinib, whereas GIST-T1derived tumors showed sensitivity to imatinib treatment (Figure 5A). Next, we investigated whether reovirus treatment shows antitumor activity against GIST-T1 or GIST-IR cells subcutaneously transplanted in nude mice. Reovirus treatment significantly inhibited tumor growth in GIST-T1 xenografts and also in GIST-IR xenografts without adverse effects (Figure 5B). Histopathological analyses of extracted tumors revealed transplanted GIST-T1 and GIST-IR tumors exhibited more apoptotic cells after reovirus therapy compared with the control. Moreover, Fas protein expression was significantly higher in GIST-T1 and GIST-IR tumor xenografts in mice treated 
with reovirus relative to those in mice without reovirus treatments (Figure 5C, 5D). In addition, the number of Ki67-positive cells was significantly decreased in GIST-T1 and GIST-IR cells treated with reovirus, and the number of cleaved caspase-3-positive cells was increased in GIST-T1 and GIST-IR cells (Figure 5D).

\section{DISCUSSION}

Although the antitumor effects of reovirus against various types of carcinoma have been reported, the efficacy of reovirus against GIST cells required clarification. In this study, we demonstrated that reovirus has a powerful oncolytic effect on GIST and imatinibresistant GIST cells, respectively.

Currently, imatinib is the first-line standard therapy for unresectable, metastatic, or recurrent GIST [25-28]. The activity and efficacy of imatinib in advanced GIST patients has been reported, showing that GISTs with specific mutations (such as PDGFRA exon18, D842V mutation, or KIT exon17, D816V mutation) have primary resistance to imatinib [29]. In addition, the development of secondary resistance to imatinib prevents highly effective therapy against GIST. Multitargeted RTK inhibitors, sunitinib or regorafenib, are often applied for the treatment of imatinib-resistant GIST; however, they have

A

GIST-T1

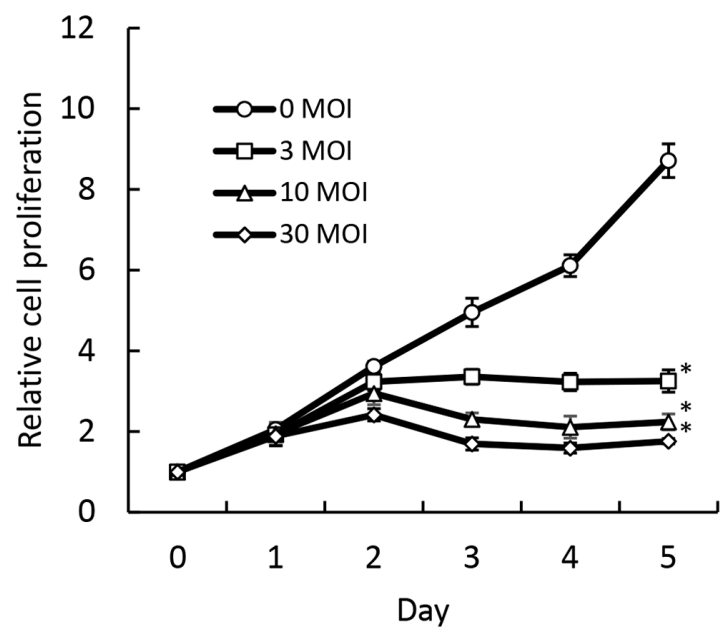

B

GIST-T1

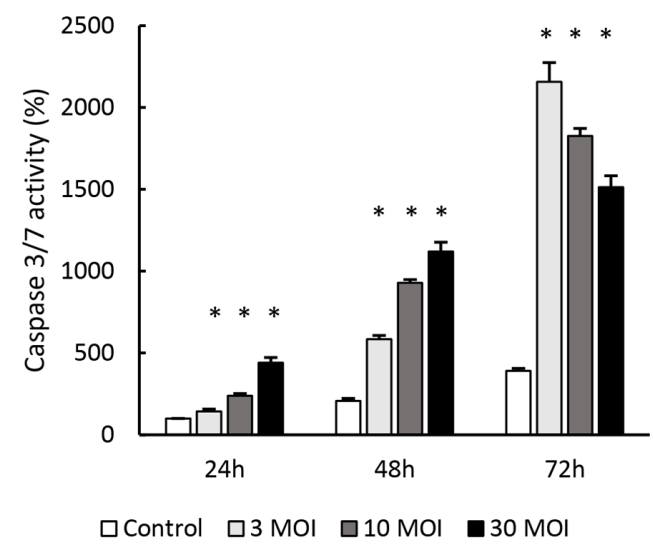

GIST-IR

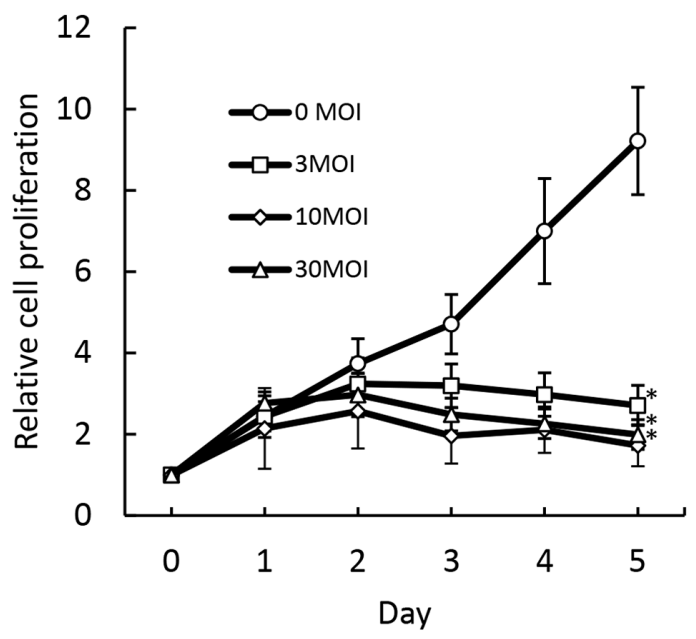

GIST-IR

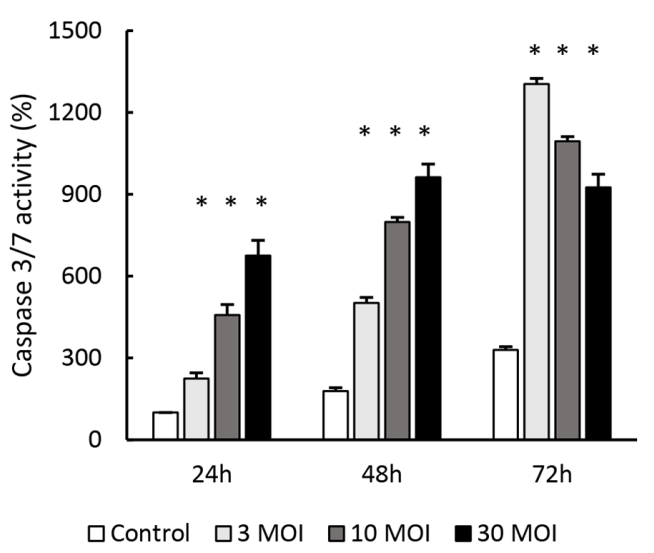

Figure 2: Growth inhibition and apoptosis induction by reovirus in GIST-T1 and GIST-IR cells in vitro. (A) $3.0 \times 10^{3}$ GIST-T1 or GIST-IR cells were plated in 96-well plates and treated with reovirus, and cell proliferation was measured by WST-8 assay. (B) $5.0 \times 10^{3}$ GIST-T1 or GIST-IR cells were plated in 96-well plates and treated with 3, 10, and 30 multiplicity of infection (MOI) of reovirus. Apoptosis induction by reovirus in each cell type was evaluated by measuring caspase-3/7 activity. Each result represents the mean \pm SD of three experiments performed in triplicate. ${ }^{*} \mathrm{P}<0.01$, compared to controls. 
Table 2: Expression profiles of apoptosis-related genes displaying at least 10-fold change in expression after treatment with $10 \mathrm{MOI}$ of reovirus in GIST-T1 cells

\begin{tabular}{|c|c|c|c|}
\hline symbol & GenbnkID & Increase & Gene name \\
\hline BCL2A1 & NM_00409 & 112.53 & BCL2-related protein A1 \\
\hline BIK & NM_001197 & 17.31 & BCL2-interacting killer \\
\hline CASP1 & NM_033292 & 110.19 & Caspase 1 , apoptosis-related cysteine peptidase \\
\hline CASP10 & NM_001230 & 14.56 & Caspase 10, apoptosis-related cysteine peptidase \\
\hline CASP4 & NM_001225 & 18.61 & Caspase 4 , apoptosis-related cysteine peptidase \\
\hline $\mathrm{CD} 40$ & NM_001250 & 21.03 & CD40 molecule, TNF receptor superfamily member 5 \\
\hline CD70 & NM_001252 & 741.88 & CD70 molecule \\
\hline FAS & NM_000043 & 14.66 & Fas (TNF receptor superfamily, member 6) \\
\hline GADD45A & NM_001924 & 28.11 & Growth arrest and DNA-damage-inducible, alpha \\
\hline HRK & NM_003806 & 255.63 & Harakiri, BCL2 interacting protein \\
\hline LTA & NM_000595 & 44.36 & Lymphotoxin alpha \\
\hline RIPK2 & NM_003821 & 45.83 & Receptor-interacting serine-threonine kinase 2 \\
\hline $\mathrm{TNF}$ & NM_000594 & 776.28 & Tumor necrosis factor \\
\hline TNFRSF10B & NM_003842 & 18.78 & Tumor necrosis factor receptor superfamily, member $10 \mathrm{~b}$ \\
\hline TNFRSF9 & NM_001561 & 887.03 & Tumor necrosis factor ligand superfamily, member 9 \\
\hline TNFSF 10 & NM_003810 & 15.02 & Tumor necrosis factor ligand superfamily, member 10 \\
\hline
\end{tabular}

limited efficacy and demonstrate higher rates of adverse events as compared to imatinib $[4,7,30]$. Therefore, the development of novel therapeutic options is crucial to overcoming these obstacles in conventional therapy for GIST patients.

Reovirus infection induces few minor symptoms including cough, sore throat, and diarrhea. Even though reovirus infections are mild and sometimes subclinical, reovirus displays selective oncolytic activity against transformed and malignant cells [9, 18, 31, 32]. Previous studies on the mechanisms of reovirus-induced killing of tumor cells suggested that Ras pathway activation was a key determinant of viral replication and subsequent oncolysis $[33,34]$. Approximately $90 \%$ of GISTs gained functional mutations in either KIT or PDGFRA that consistently drive RTK pathways without activation by their ligands. Activated RTKs subsequently lead to activation of the Ras pathway, and thus we speculated that reovirus might display an antitumor effect against GIST. Indeed, our present study revealed that reovirus treatment induced apoptotic cell death in GIST cells regardless of their sensitivity to imatinib (Figures 2A, 4B). However, it remains unclear whether reovirus has antitumor activity against primary imatinib-resistant GIST cells. In addition, the efficacy of reovirus against secondary imatinib-resistant GIST with acquired point mutations to $K I T$ in exon 13,14 , and 17 , which is detected in $40-80 \%$ of patients progressing on imatinib, and PDGFRA exon 18 mutation, identified in a subset of GIST refractory to imatinib [2, 19, 20, 35], is not clarified in this study. We could not identify any of these specific mutations related to secondary imatinib-resistance in GIST-IR cells. Another possible mechanism of imatinib resistance is KIT gene amplification, and other oncogenes and tumor suppressor genes may also be responsible for imatinib resistance in GIST, for example, silencing of the PTEN gene or activation of ERK [2, 36, 37]. Furthermore, it is reported that $\mathrm{PI} 3 \mathrm{~K} / \mathrm{Akt} / \mathrm{mammalian}$ target of rapamycin (mTOR) signaling appears particularly important in imatinibresistant GIST [35, 38, 39]. In our established GIST-IR cells, RTK phosphorylation arrays revealed the activation of tyrosine kinase receptors and their downstream targets, despite treatment with high concentrations of imatinib (Figure 1C, 1D, Supplementary Figure 1), which enable GIST-IR cells to resist imatinib cytotoxicity.

As mentioned above, we focused on TRAIL and Fas as two key molecules among the genes involved in reovirus-induced apoptosis. TRAIL belongs to the tumor necrosis factor (TNF) family of proteins and induces apoptosis through its receptors DR4 and DR5 in a wide variety of tumor cells, but does not cause toxicity in the majority of normal cells [40]. We have previously reported that reovirus-induced apoptosis is mediated by TRAIL and is associated with its release from infected cells in gastric 


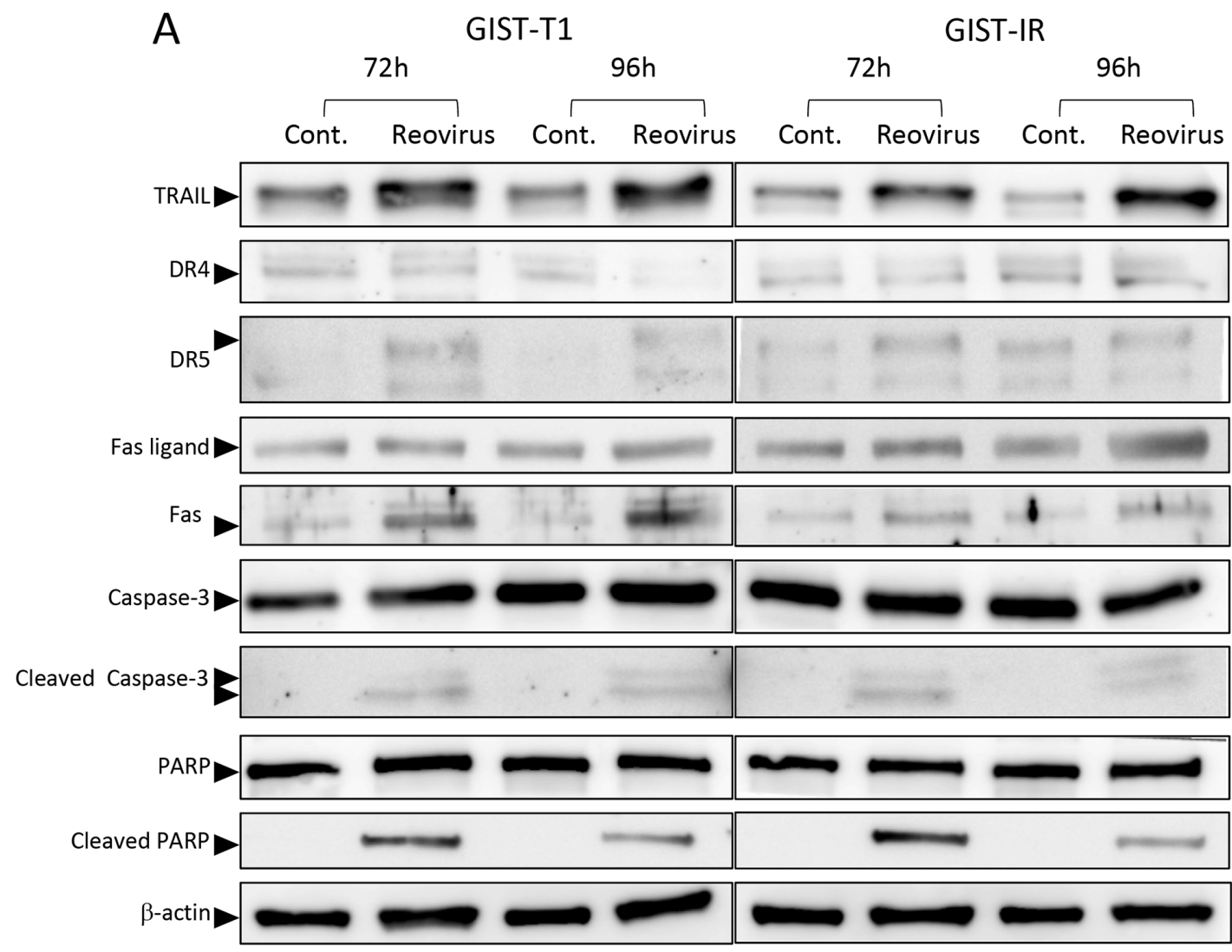

B

GIST-T1

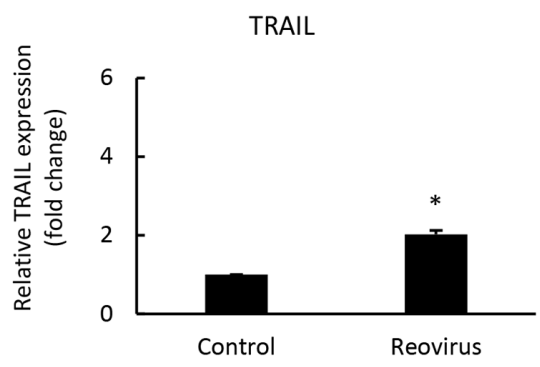

Fas

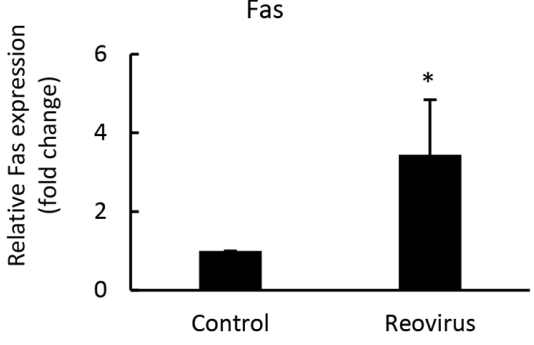

GIST-IR

TRAIL

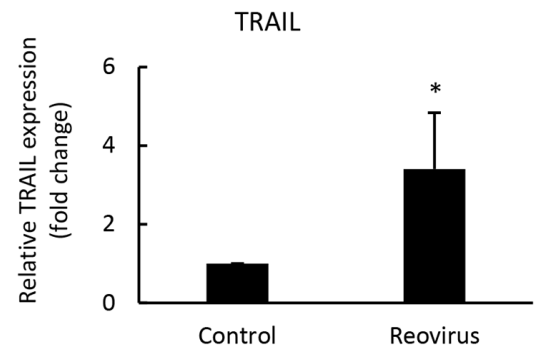

Fas

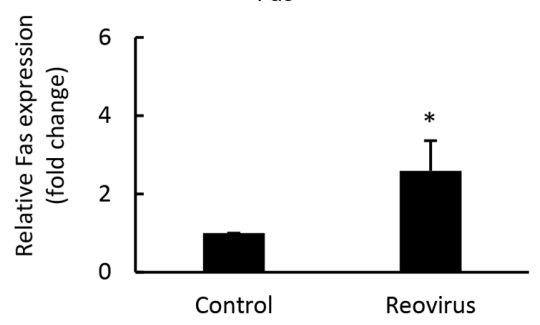

Figure 3: Reovirus enhanced TRAIL and Fas expression in GIST-T1 and GIST-IR cells. (A) Western blot analysis showed changes in apoptosis-related proteins, TRAIL, cell surface death receptors (DR) 4, DR5, Fas ligand, Fas, caspase-3, and poly ADP ribose polymerase (PARP) in GIST-T1 and GIST-IR cells following treatment with 10 MOI of reovirus for 72 or 96 hours. (B) Relative expression of TRAIL and FAS proteins in GIST-T1 and GIST-IR with or without $10 \mathrm{MOI}$ of reovirus for 96 hours quantified by densitometry using imageJ software. Each result represents the mean \pm SD of three experiments. ${ }^{*}<0.01$, compared to controls. 
A

GIST-T1

GIST-IR

GIST-T1

GIST-IR
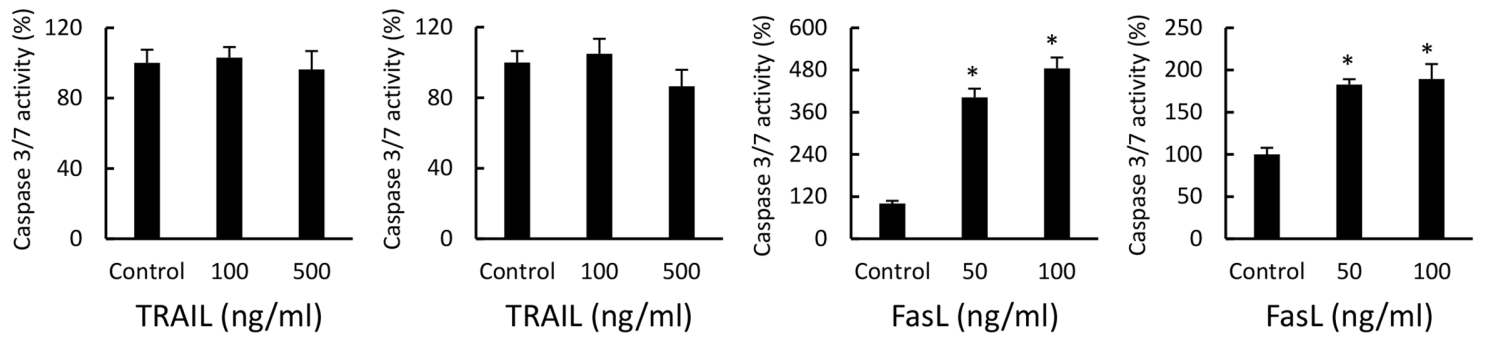

B
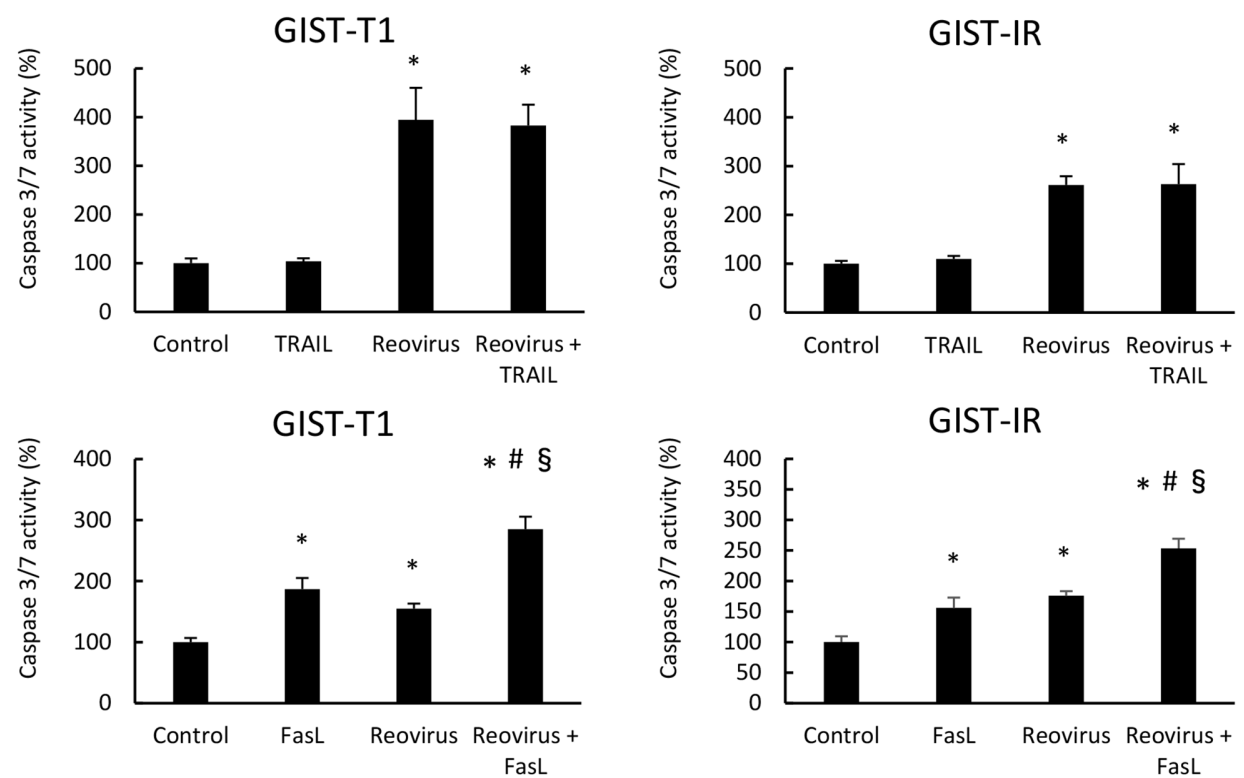

C

GIST-T1
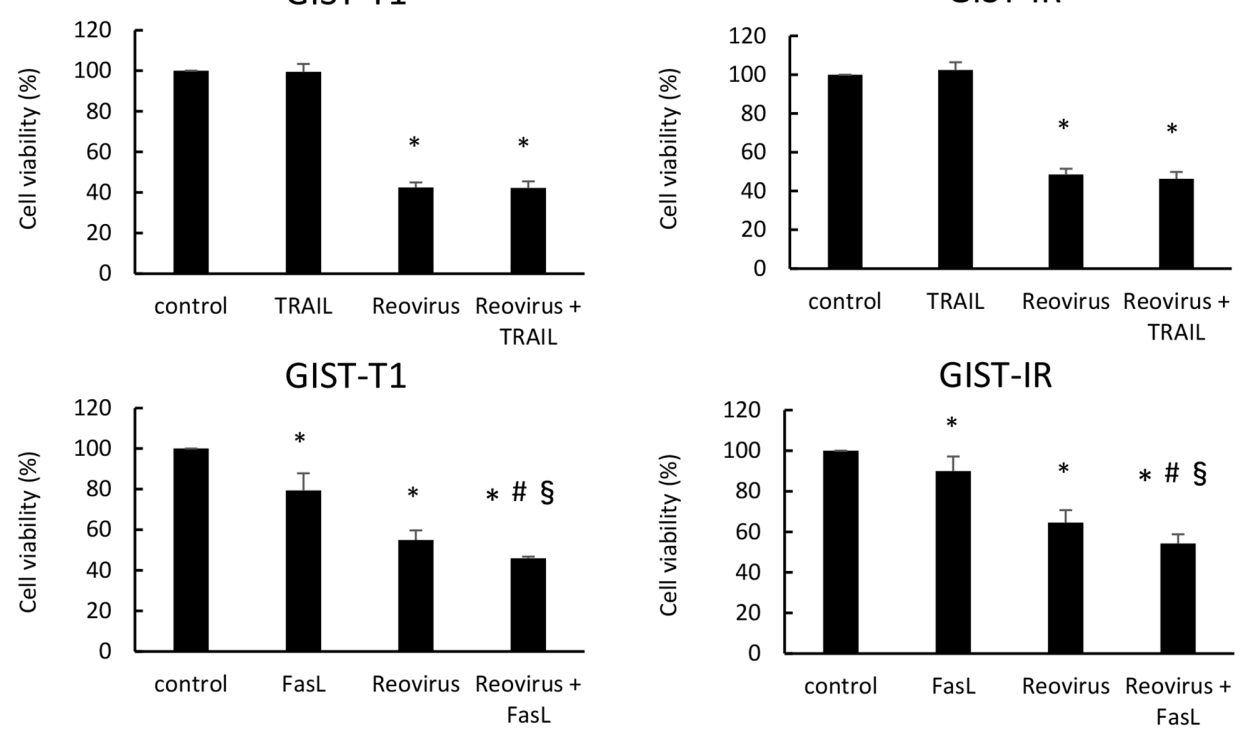

Figure 4: Combination treatment of FasL and reovirus significantly induced apoptosis in GIST-T1 and GIST-IR cells. (A) Caspase 3/7 activity was measured in GIST-T1 and GIST-IR cells treated with TRAIL or FasL for 24 hours. (B) Caspase 3/7 activity was evaluated in GIST-T1 and GIST-IR cells treated with $10 \mathrm{MOI}$ reovirus treatments for 24 hours, and subsequently treated with TRAIL or FasL for 24 hours. (C) Cell viability was evaluated in GIST-T1 and GIST-IR cells treated with 10 MOI reovirus treatments for 48 hours, and subsequently treated with TRAIL or FasL for 48 hours. Each result represents the mean \pm SD of three experiments performed in triplicate. ${ }^{*} \mathrm{P}<0.01$, compared to control; ${ }^{\mathrm{P}}<0.01$, compared to FasL alone; ${ }^{\circledR} \mathrm{P}<0.01$, compared to reovirus alone. 

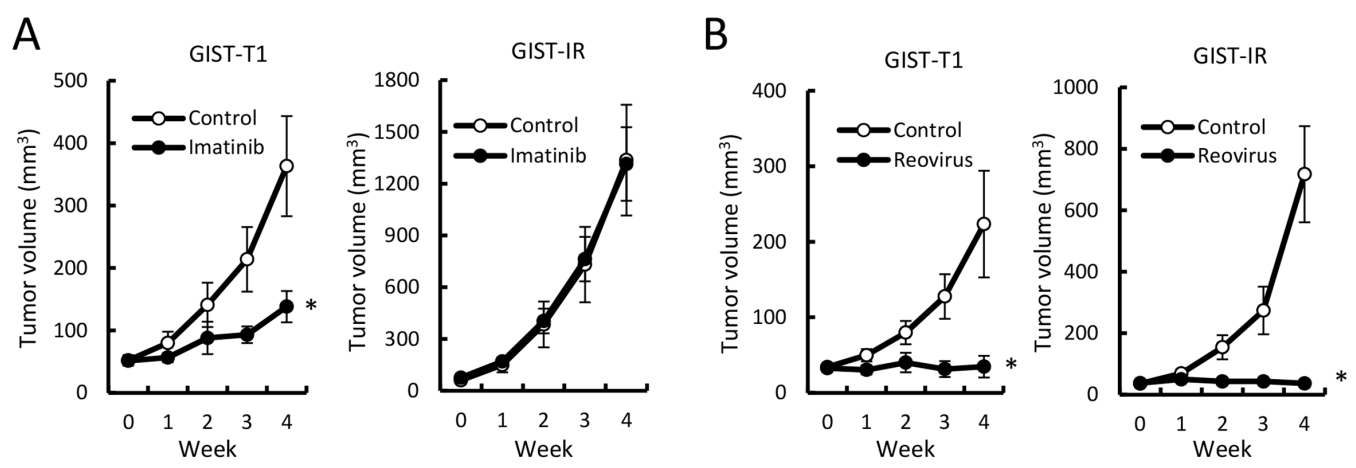

C
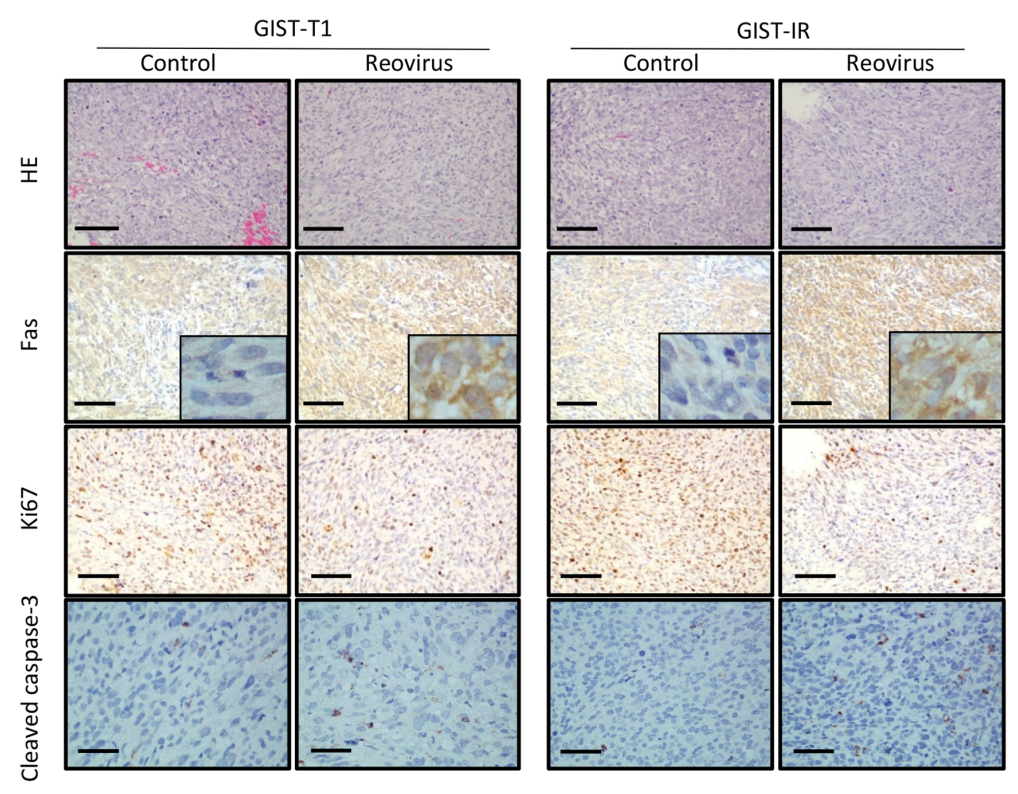

Scale bars $=100 \mu \mathrm{m}$

D

GIST-T1
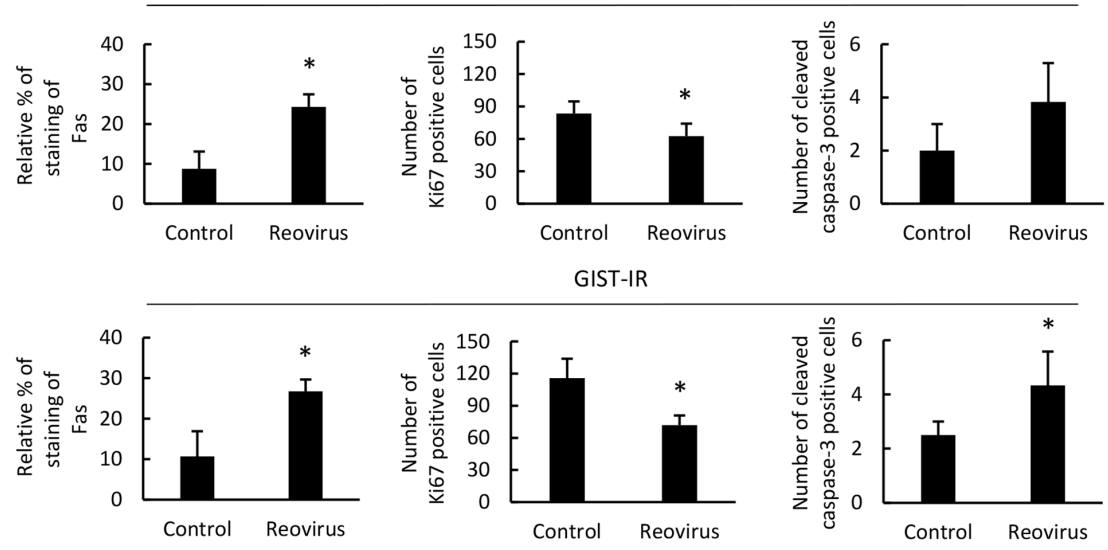

Figure 5: Imatinib resistance in GIST-IR cells and efficacy of reovirus therapy against GIST-T1 and GIST-IR cells in vivo. Groups of BALB/c nude mice ( $\mathrm{n}=5$ mice per group) were injected subcutaneously with $3 \times 10^{6}$ cells of GIST-T1 or GIST-IR cells, and grown to palpable size for 14 days. (A) Mice were treated with imatinib dissolved in water at a dose of $40 \mathrm{mg} / \mathrm{kg} / \mathrm{day}$ or water alone by oral administration for 4 weeks. (B) Mice were treated with a direct intra-tumor injection of $1 \times 10^{8}$ pfu reovirus weekly for 4 weeks. Tumor volumes were estimated once a week. Data are shown as means $\pm \mathrm{SE}{ }^{*} \mathrm{P}<0.05$, compared to control. (C) Representative images of hematoxylin and eosin (HE) and Fas, Ki67, and Cleaved caspase-3 staining of subcutaneously transplanted GIST-T1 and GIST-IR cells treated with or without injection of $1 \times 10^{8}$ pfu reovirus weekly for 4 weeks. (D) Quantification of Fas expression, Ki67-positive cells and cleaved caspase-3-positive cells in GIST-T1 or GIST-IR xenografts with or without injection of $1 \times 10^{8}$ pfu reovirus weekly for 4 weeks. Data are shown as means $\pm \mathrm{SD}{ }^{*} \mathrm{P}<0.05$, compared to controls. 
cancer cells. Others have also reported that reovirus promotes apoptosis through the expression of DR5 and the release of TRAIL from reovirus infected cells, and exogenous TRAIL was reported to enhance reovirusinduced apoptosis $[22,23,41]$. In the present study, TRAIL did not induce apoptosis in GIST cells, and TRAIL did not enhance the cytotoxic effects of reovirus on GIST cells even after reovirus stimulation. In GIST cells, TRAIL expression is enhanced as a result of reovirus-induced apoptosis, even though TRAIL may not be involved in the mechanism of reovirus action. In contrast, Fas also belongs to the TNF family of death receptors, and induces apoptosis when bound to its ligand, FasL. Studies have demonstrated that some cancer cells are susceptible to Fas agonistic antibodies [42, 43]. As for the correlation between reovirus and Fas, it has been reported that Fas is implicated in reovirus-mediated apoptotic signaling in the mouse brain [44]. We demonstrated that FasL mediated apoptosis in GIST-T1 and GIST-IR cells (Figure 4A), in accordance with previous reports [24]. Moreover, we demonstrated the combination effects of reovirus and FasL against GIST-T1 and GIST-IR cells (Figure 4B). These results indicate that the Fas-FasL pathway plays an important role in reovirus-induced apoptosis in GIST cells regardless of their resistance to imatinib. Although the current study focused on the antitumor activity of reovirus for GIST as monotherapy, our study suggests the potential utility of combination treatment of reovirus and FasL against GIST.

The present in vivo study demonstrated that fourweek treatment with imatinib showed a modest antitumor effect against GIST-T1 cells. Subcutaneous transplanted GIST-IR cells were completely resistant to imatinib treatment in our xenograft model. In contrast, significantly slower tumor growth was observed in mice treated with reovirus without side effects, such as weight loss and diarrhea, in both GIST-T1 and GIST-IR cells (Figure 5B, Supplementary Figure 4). Histopathologically, reovirus induced apoptotic changes and reduced cell growth activity in xenograft tumor cells. Reovirus also enhanced Fas expression in transplanted GIST-T1 and GIST-IR cells, which also indicated the importance of the Fas-FasL pathway in reovirus-induced apoptosis.

In conclusion, we demonstrated that oncolytic reovirus induced apoptosis and suppressed tumor growth in GIST, regardless of its sensitivity to imatinib. Despite the limitations of our imatinib-resistant GIST model, reovirus might have potential utility as an alternative GIST therapy, irrespective of imatinib sensitivity. This is because the mechanism of reovirus antitumor activity is completely different from RTK inhibitors such as imatinib. Furthermore, primary and secondary imatinib resistance is mainly attributable to mutations of RTKs that interfere with drug binding. Moreover, reovirus therapy is potentially more advantageous than the conventional GIST therapy with its associated adverse effects.

\section{MATERIALS AND METHODS}

\section{Reagents}

Imatinib was purchased from Sigma-Aldrich (St. Louis, MO) and dissolved in DMSO to a stock concentration of $10^{-2} \mathrm{M}$, and then stored at $-80^{\circ} \mathrm{C}$ until use. The DMSO concentration of the medium did not exceed $0.01 \%$ in order to avoid any effect on GIST-T1 cell viability.

\section{Cell culture}

The human GIST cell line, GIST-T1, provided by COSMO BIO (Tokyo, Japan), was established and has been characterized in detail by Taguchi et al. [45]. GIST-T1 has an activating mutation in KIT exon 11 and is sensitive to imatinib. The cells were originally purchased in 2014, and all experiments in this study were carried out using cells within 20 passages. Cells were authenticated through morphological examination and expression of c-kit. Imatinib-resistant GIST, GIST-IR, was established by culturing cells with increasing concentrations of imatinib $(5-80 \mathrm{nM})$ for 6 months [36, 37]. GIST-T1 and GIST-IR were cultured in high $(4500 \mathrm{mg} / \mathrm{L})$ glucose Dulbecco's Modified Eagle's Medium (Wako Pure Chemical Industries, Osaka, Japan) supplemented with $10 \% \mathrm{FBS}$ under $5 \% \mathrm{CO}_{2}$ at $37^{\circ} \mathrm{C}$. Microbial contamination test of both cell lines was conducted by an outsourced organization, ICLAS Monitoring Center (Kanagawa, Japan).

\section{Mutation analysis of KIT and PDGFRA}

Sequence analysis was utilized to examine whether secondary mutations occurred in KIT and PDGFRA genes in GIST-IR cells. Total RNA was isolated with $16 \mathrm{LEV}$ simplyRNA Cells and Tissue Kits (Promega, Madison, WI) and the same amounts of RNA were reversetranscribed into cDNA using a High-Capacity cDNA Reverse Transcription kit (Applied Biosystems, Tokyo, Japan) according to the manufacturer's instructions. Primer sets for PCR are shown in Table 1. PCR was carried out using a TaKaRa PCR Thermal Cycler (Takara, Shiga, Japan), and purified PCR products were sequenced by the ABI PRISM 310 Genetic Analyzer (Applied Biosystems, Foster City, CA). The amplification protocol was $94^{\circ} \mathrm{C}$ for 1 minute, then 30 cycles at $98^{\circ} \mathrm{C}$ for 10 seconds, $68^{\circ} \mathrm{C}$ for 30 seconds.

\section{Cell viability assay}

Cell viability was analyzed using the WST-8 cell proliferation assay. Cells were seeded into 96-well culture plates at a concentration of $5 \times 10^{3}$ cells $/ 100 \mu \mathrm{L} /$ well and incubated overnight. Cells were then exposed to imatinib within the concentration range of $25-3200 \mathrm{nM}$ on day 0 . 
Cell survival was evaluated using the Cell Counting Kit8 (Dojindo Laboratories, Kumamoto, Japan) according to the manufacturer's protocol, and the absorption at 450 $\mathrm{nm}$ was measured with a microplate spectrophotometer (SPECTRA MAX340; Molecular Devices). Furthermore, to test the combination efficacy of reovirus with TRAIL or FasL, GIST-T1 and GIST-IR cells were infected with reovirus at $10 \mathrm{MOI}$, and after 48 hours, cells were treated with TRAIL or FasL. Forty-eight hours after TRAIL or FasL treatment, cell viability was assessed using the Cell Counting Kit-8. All experiments were performed in more than five samples and repeated at least three times. Viability inhibition (\%) was calculated as follows: (measured value of treated group - blank) / (measured value of control group - blank) $\times 100 \%$. The IC50 was calculated by probit analysis.

\section{Cell proliferation assay}

Cell proliferation was analyzed using the WST- 8 cell proliferation assay. Cells were seeded into 96-well culture plates at a concentration of $3 \times 10^{3}$ cells $/ 100 \mu \mathrm{L} /$ well and incubated overnight. Cells were then treated with reovirus at multiplicity of infection (MOI) of 3,10, and 30 on day 0 . Cell proliferation was evaluated using the Cell Counting Kit-8 (Dojindo Laboratories, Kumamoto, Japan) according to the manufacturer's protocol, and the absorption at 450 nm was measured with a microplate spectrophotometer (SPECTRA MAX340; Molecular Devices). We observed proliferative capacity, calculating the values from day 1 to day 5 with the number of cells on day 0 set to 1 .

\section{Apoptosis assays}

Apoptosis induced by reovirus treatment was quantified by measuring caspase-3/7 activity with the Caspase-Glo 3/7 Assay System (Promega). GIST-T1 and GIST-IR cells were seeded into 96-well culture plates at a concentration of $3 \times 10^{3}$ cells $/ 100 \mu \mathrm{L} /$ well and incubated overnight, and then treated with reovirus (10 MOI), tumor necrosis factor-related apoptosis-inducing ligand (TRAIL) or Fas ligand (FasL). After the indicated times, the caspase-3/7 activity of the cells was measured by adding an aliquot of the homogenous caspase-3/7 reagent to each well, incubating the plate for 1 hour at room temperature, and measuring the fluorescence intensity with a fluorescent plate reader. Furthermore, caspase-3/7 activities of the cells treated with $10 \mathrm{MOI}$ reovirus in combination with caspase $3 / 7$ inhibitor (SANTA CRUZ Biotechnology) or BID inhibitor (SANTA CRUZ Biotechnology) were measured using the Caspase-Glo 3/7 Assay System. To test the combination efficacy of reovirus with TRAIL or FasL, GIST-T1 and GIST-IR cells were treated with TRAIL or FasL, and after 24 hours, cells were infected with reovirus at 10 MOI. Forty-eight hours after reovirus treatment, cell apoptosis was assessed using the Caspase-Glo 3/7 Assay System.

\section{Quantitative reverse transcription-polymerase chain reaction}

To investigate differences in gene expression induced by reovirus infection, reverse transcriptionpolymerase chain reaction (RT-PCR) was performed using a human apoptosis $\mathrm{RT}^{2}$ Profiler PCR array (Qiagen, Hilden, Germany) containing 84 different apoptosisassociated genes and five housekeeping genes (ACTB, B2M, GAPDH, HPRT1, and RPLP0). We assessed the mRNA expression profiles of GIST-T1 and GIST-IR cells treated with reovirus at $10 \mathrm{MOI}$ for 48 hours. Realtime quantitative RT-PCR analyses were performed using an ABI 7500 Fast Real-Time PCR system (Applied Biosystems) according to the manufacturer's recommendations. Results were analyzed using PCR Array Data Analysis on the Qiagen web page (http://www. qiagen.com/us/shop/genes-and-pathways/data-analysiscenter-overview-page/). To normalize transcript levels, we chose the "automatic selection from full plate" method.

\section{Western blotting}

Cells were washed with PBS (Sigma-Aldrich) 3 times and then added to $1 \mathrm{~mL}$ of cell lysis buffer (Cell Signaling Technology, Danvers, MA) containing 20 mmol/L Tris- $\mathrm{HCl}$ (pH 7.5), $150 \mathrm{mmol} / \mathrm{L} \mathrm{NaCl}, 1 \mathrm{mmol} / \mathrm{L}$ $\mathrm{Na}_{2}$ EDTA, $1 \mathrm{mmol} / \mathrm{L}$ EGTA, 1\% Triton, $2.5 \mathrm{mmol} / \mathrm{L}$ sodium pyrophosphate, $1 \mathrm{mmol} / \mathrm{L} \beta$-glycerophosphate, $1 \mathrm{mmol} / \mathrm{L} \mathrm{Na}_{3} \mathrm{VO}_{4}$, and $1 \mu \mathrm{g} / \mathrm{mL}$ leupeptin. Cells were disrupted for 15 seconds on ice using a Bioruptor sonicator (Cosmo Bio, Tokyo, Japan) and centrifuged at 15,000 rpm for 20 minutes at $4^{\circ} \mathrm{C}$. Each sample was normalized to an equal protein concentration using a Protein Assay Kit (Bio-Rad Laboratories, Hercules, CA). Equal quantities of $2 \times$ SDS-PAGE sample buffer $[0.5 \mathrm{M}$ Tris- $\mathrm{HCl}(\mathrm{pH}$ 7.2), 1\% SDS, $100 \mathrm{mmol} / \mathrm{L} \beta$-mercaptoethanol, and $0.01 \%$ bromophenol blue] were added to each sample, and samples were boiled for 5 minutes at $100^{\circ} \mathrm{C}$. Aliquots of each sample were separated by SDS-PAGE on a $10 \%$ gel and transferred to a nitrocellulose membrane. The membrane was blocked with 5\% skim milk in PBS for 1 hour at room temperature, followed by incubation with the primary antibodies against TRAIL, cell surface death receptor (DR) 4, DR5, Fas, FasL (Abcam, Cambridge, MA), phosphorylated c-Kit (Tyr719), phosphorylated Akt (Ser473), phosphorylated ERK1/2 (Thr202/Tyr204), caspase-3, cleaved caspase-3, poly ADP ribose polymerase (PARP), cleaved PARP (Cell Signaling Technology) and $\beta$-actin (Sigma-Aldrich) overnight at $4^{\circ} \mathrm{C}$. Membranes were washed with $0.05 \%$ Tween 20 in PBS 3 times at 5 -minutes intervals, incubated with the secondary antibody for 1 hour at room temperature, and washed again with $0.05 \%$ Tween 20 in PBS 3 times at 5-minute intervals. The membrane was incubated with Western blotting detection reagent, ECL Prime (GE Healthcare, Buckinghamshire, UK) for 5 minutes at room temperature and filmed using 
ImageQuant LAS 4000 (GE Healthcare). Quantification of Fas and TRAIL protein expression corrected with $\beta$-actin in western blotting was performed using ImageJ image analysis software (https://imagej.nih.gov/ij).

\section{Receptor tyrosine kinase phosphorylation array}

PathScan ${ }^{\circledR}$ RTK Signaling Antibody Array Kit (Cell Signaling Technology) is a slide-based antibody array founded upon the sandwich immunoassay principle. The array kit allows for the simultaneous detection of 28 receptor tyrosine kinases and 11 important signaling nodes, when phosphorylated at tyrosine or other residues. Targetspecific capture antibodies have been spotted in duplicate onto nitrocellulose-coated glass slides. Whole cell lysates of GIST-T1 and GIST-IR cells exposed to imatinib are incubated on the slide, followed by a biotinylated detection antibody cocktail. Streptavidin-conjugated HRP and LumiGLO ${ }^{\circledR}$ reagent were then used to visualize the bound detection antibody by chemiluminescence. Slides were imaged using ImageQuant LAS 4000 (GE Healthcare). Quantification of tyrosine kinase receptors and cell signaling intermediates in the receptor tyrosine kinase (RTK) phosphorylation array was performed using ImageJ image analysis software.

\section{Tumor xenograft experiments}

Pathogen-free female nude mice (BALB/c Slc-nu/ nu), 6 to 8 weeks of age, with a body weight of 18 to $22 \mathrm{~g}$, were obtained from Shizuoka Laboratory Animal Center (Hamamatsu, Japan). Xenograft tumor models were established by subcutaneously implanting $3 \times 10^{6}$ GIST-T1 or GIST-IR cells in $100 \mu \mathrm{L}$ of PBS and equivalent amounts of matrigel (Corning, NY). Mice were then treated with imatinib or reovirus. Imatinib was dissolved in a small amount of DMSO and added to water. Some of the mice were treated daily with $40 \mathrm{mg} / \mathrm{kg}$ imatinib by oral administration for 4 weeks $(n=5)$. The other mice were treated with direct intratumor injections of reovirus at a dose of $1 \times 10^{8}$ plaque-forming units (pfu) per mouse weekly for 4 weeks $(n=5)$. The dose of reovirus was chosen based on our previous study [22]. The maximum tumor diameter (L) and the diameter at right angles to that axis (W) were measured weekly using calipers, and the volume was calculated according to the formula, (L $\left.\times \mathrm{W}^{2}\right) / 2[22,37]$. Tumor size was measured and antitumor activity of imatinib or reovirus was evaluated until 4 weeks after treatment. Subsequently, transplanted tumors were excised and fixed in formalin for histological analysis after euthanasia. There were no adverse effects, including weight loss and infection, observed throughout the treatment period. The procedures in these experiments were approved by the Nagoya City University Center for Experimental Animal Science, and the mice were cared for according to the guidelines of the Nagoya City University for Animal Experiments.

\section{Immunohistochemistry}

Subcutaneous tumors in nude mice were removed and fixed in $10 \%$ buffered formalin for 24 hours. Formalin-fixed and paraffin-embedded sections $(4 \mu \mathrm{m})$ were used for immunohistochemistry. Sections were stored dry until use for histological analysis. After preincubation with $0.3 \%$ hydrogen peroxide in methanol for 30 minutes to block endogenous peroxidase activity, sections were rinsed in PBS. Fas, Ki67 and cleaved caspase- 3 were visualized immunohistochemically by the streptavidin-biotin method using 1:400 rabbit anti-Fas antibody (Abcam), 1:100 rabbit anti-Ki67 antibody (Leica Biosystems, Nussloch, Germany), or 1:400 rabbit anticleaved caspase-3 antibody (Cell Signaling Technology) and the Histofine SAB-PO ${ }^{\circledR}$ Kit (Nichirei, Tokyo, Japan), according to the manufacturer's protocol. Sections were rinsed and incubated sequentially with secondary antibody (goat biotinylated anti-rabbit IgG antibody) and with the streptavidin-biotin-peroxidase complex. Sections were then washed with PBS, incubated in diaminobenzidine solution containing $0.003 \%$ hydrogen peroxide and 10 $\mathrm{mM}$ sodium azide, followed by a Mayer hematoxylin counterstain, and the peroxidase reaction was developed. Sections were then dehydrated through graded ethanol solutions $(70 \%-100 \%)$. For quantification, the number of Ki67-positive cells or cleaved caspase-3-positive cells in the field, approximately $70,000 \mu \mathrm{m}^{2}$, was counted at $400 \times$ magnification randomly. Only cells stained precisely were counted as Ki67-positive or caspase-3positive cells to avoid counting cells with non-specific staining. For objective cell counts, two independent researchers identified the positive-stained cells blindly; then observers, blinded to the treatment condition, performed the cell counts. The counts from six fields were averaged. Observations were obtained from at least three independent experiments. To quantify Fas protein expression in the sections at $200 \times$ magnification, we used ImageJ software with immunohistochemistry profiler plugin as described previously by Varghese et al [46].

\section{Statistical analysis}

All statistical analyses were performed with EZR (Saitama Medical Center, Jichi Medical University, Saitama, Japan), which is a graphical user interface for R (The R Foundation for Statistical Computing, Vienna, Austria). More precisely, it is a modified version of $\mathrm{R}$ commander designed to add statistical functions frequently used in biostatistics [47]. Mann-Whitney U test was used for continuous variables. $P$ values of less than 0.05 were considered to indicate statistical significance. 


\section{Abbreviations}

GIST: Gastrointestinal stromal tumor; PDGFRA: Platelet-derived growth factor receptor alpha; RTK: Receptor tyrosine kinase; PCR: Polymerase chain reaction; TRAIL: TNF-related apoptosis-inducing ligand; FasL: Fas ligand; TNF: Tumor necrosis factor.

\section{Author contributions}

YI and EK designed all experiments. YI, YS, MA, $\mathrm{HK}$, and EK performed experiments. RNJ and TJ assisted in the conception of the research hypothesis, reviewed manuscript. YI and EK wrote, edited, and proofread the manuscript. All authors read and approved the final manuscript.

\section{ACKNOWLEDGMENTS}

We would like to thank Mrs. Yukimi Ito from Nagoya City University for her technical assistance.

\section{CONFLICTS OF INTEREST} interest.

All authors state that they have no conflicts of

\section{FUNDING}

This work was supported by Grants-in-Aid for Scientific Research (C) from the Japan Society for the Promotion of Science (JSPS), KAKENHI Grant Number $15 \mathrm{~K} 09060$ and a Grant-in-Aid from the $24^{\text {th }}$ General Assembly of the Japanese Association of Medical Sciences.

\section{REFERENCES}

1. Rubin BP, Heinrich MC, Corless CL. Gastrointestinal stromal tumour. Lancet. 2007; 369: 1731-41. https://doi. org/10.1016/s0140-6736(07)60780-6.

2. Lopes LF, Bacchi CE. Imatinib treatment for gastrointestinal stromal tumour (GIST). J Cell Mol Med. 2010; 14: 42-50. https://doi.org/10.1111/j.1582-4934.2009.00983.x.

3. Verweij J, Casali PG, Zalcberg J, LeCesne A, Reichardt P, Blay JY, Issels R, van Oosterom A, Hogendoorn PC, Van Glabbeke M, Bertulli R, Judson I. Progression-free survival in gastrointestinal stromal tumours with high-dose imatinib: randomised trial. Lancet. 2004; 364: 1127-34. https://doi. org/10.1016/s0140-6736(04)17098-0.

4. Demetri GD, van Oosterom AT, Garrett CR, Blackstein ME, Shah MH, Verweij J, McArthur G, Judson IR, Heinrich MC, Morgan JA, Desai J, Fletcher CD, George S, et al. Efficacy and safety of sunitinib in patients with advanced gastrointestinal stromal tumour after failure of imatinib: a randomised controlled trial. Lancet. 2006; 368: 1329-38. https://doi.org/10.1016/s0140-6736(06)69446-4.

5. Antonescu CR, Besmer P, Guo T, Arkun K, Hom G, Koryotowski B, Leversha MA, Jeffrey PD, Desantis D, Singer S, Brennan MF, Maki RG, DeMatteo RP. Acquired resistance to imatinib in gastrointestinal stromal tumor occurs through secondary gene mutation. Clin Cancer Res. 2005; 11: 4182-90. https://doi.org/10.1158/1078-0432. ccr-04-2245.

6. Garner AP, Gozgit JM, Anjum R, Vodala S, Schrock A, Zhou T, Serrano C, Eilers G, Zhu M, Ketzer J, Wardwell S, Ning Y, Song Y, et al. Ponatinib inhibits polyclonal drugresistant KIT oncoproteins and shows therapeutic potential in heavily pretreated gastrointestinal stromal tumor (GIST) patients. Clin Cancer Res. 2014; 20: 5745-55. https://doi. org/10.1158/1078-0432.ccr-14-1397.

7. Demetri GD, Reichardt P, Kang YK, Blay JY, Rutkowski P, Gelderblom H, Hohenberger P, Leahy M, von Mehren M, Joensuu H, Badalamenti G, Blackstein M, Le Cesne A, et al. Efficacy and safety of regorafenib for advanced gastrointestinal stromal tumours after failure of imatinib and sunitinib (GRID): an international, multicentre, randomised, placebo-controlled, phase 3 trial. Lancet. 2013; 381: 295302. https://doi.org/10.1016/s0140-6736(12)61857-1.

8. Kelly K, Nawrocki S, Mita A, Coffey M, Giles FJ, Mita M. Reovirus-based therapy for cancer. Expert Opin Biol Ther. 2009; 9: 817-30. https://doi. org/10.1517/14712590903002039.

9. Gong J, Mita MM. Activated ras signaling pathways and reovirus oncolysis: an update on the mechanism of preferential reovirus replication in cancer cells. Front Oncol. 2014; 4: 167. https://doi.org/10.3389/fonc.2014.00167.

10. Coffey MC, Strong JE, Forsyth PA, Lee PW. Reovirus therapy of tumors with activated Ras pathway. Science. 1998; 282: 1332-4.

11. Norman KL, Hirasawa K, Yang AD, Shields MA, Lee PW. Reovirus oncolysis: the Ras/RalGEF/p38 pathway dictates host cell permissiveness to reovirus infection. Proc Natl Acad Sci U S A. 2004; 101: 11099-104. https://doi. org/10.1073/pnas.0404310101.

12. Park EH, Park EH, Cho IR, Srisuttee R, Min HJ, Oh MJ, Jeong YJ, Jhun BH, Johnston RN, Lee S, Koh SS, Chung YH. CUG2, a novel oncogene confers reoviral replication through Ras and p38 signaling pathway. Cancer Gene Ther. 2010; 17: 307-14. https://doi.org/10.1038/cgt.2009.83.

13. Tyler KL, Squier MK, Rodgers SE, Schneider BE, Oberhaus SM, Grdina TA, Cohen JJ, Dermody TS. Differences in the capacity of reovirus strains to induce apoptosis are determined by the viral attachment protein sigma 1. J Virol. 1995; 69: 6972-9.

14. Rodgers SE, Barton ES, Oberhaus SM, Pike B, Gibson CA, Tyler KL, Dermody TS. Reovirus-induced apoptosis of MDCK cells is not linked to viral yield and is blocked by Bcl-2. J Virol. 1997; 71: 2540-6. 
15. Wilcox ME, Yang W, Senger D, Rewcastle NB, Morris DG, Brasher PM, Shi ZQ, Johnston RN, Nishikawa S, Lee PW, Forsyth PA. Reovirus as an oncolytic agent against experimental human malignant gliomas. J Natl Cancer Inst. 2001; 93: 903-12.

16. Thirukkumaran C, Morris DG. Oncolytic viral therapy using reovirus. Methods Mol Biol. 2015; 1317: 187-223. https://doi.org/10.1007/978-1-4939-2727-2_12.

17. Morris DG, Feng X, DiFrancesco LM, Fonseca K, Forsyth PA, Paterson AH, Coffey MC, Thompson B. REO-001: a phase I trial of percutaneous intralesional administration of reovirus type 3 dearing (Reolysin(R)) in patients with advanced solid tumors. Invest New Drugs. 2013; 31: 696706. https://doi.org/10.1007/s10637-012-9865-z.

18. Gong J, Sachdev E, Mita AC, Mita MM. Clinical development of reovirus for cancer therapy: an oncolytic virus with immune-mediated antitumor activity. World J Methodol. 2016; 6: 25-42. https://doi.org/10.5662/wjm. v6.i1.25.

19. Wardelmann E, Merkelbach-Bruse S, Pauls K, Thomas N, Schildhaus HU, Heinicke T, Speidel N, Pietsch T, Buettner R, Pink D, Reichardt P, Hohenberger P. Polyclonal evolution of multiple secondary KIT mutations in gastrointestinal stromal tumors under treatment with imatinib mesylate. Clin Cancer Res. 2006; 12: 1743-9. https://doi.org/10.1158/1078-0432.ccr-05-1211.

20. Heinrich MC, Marino-Enriquez A, Presnell A, Donsky RS, Griffith DJ, McKinley A, Patterson J, Taguchi T, Liang $\mathrm{CW}$, Fletcher JA. Sorafenib inhibits many kinase mutations associated with drug-resistant gastrointestinal stromal tumors. Mol Cancer Ther. 2012; 11: 1770-80. https://doi. org/10.1158/1535-7163.mct-12-0223.

21. Duensing S, Duensing A. Targeted therapies of gastrointestinal stromal tumors (GIST)--the next frontiers. Biochem Pharmacol. 2010; 80: 575-83. https://doi. org/10.1016/j.bcp.2010.04.006.

22. Hamano S, Mori Y, Aoyama M, Kataoka H, Tanaka M, Ebi M, Kubota E, Mizoshita T, Tanida S, Johnston RN, Asai K, Joh T. Oncolytic reovirus combined with trastuzumab enhances antitumor efficacy through TRAIL signaling in human HER2-positive gastric cancer cells. Cancer Lett. 2015; 356: 846-54. https://doi.org/10.1016/j. canlet.2014.10.046.

23. Clarke P, Meintzer SM, Gibson S, Widmann C, Garrington TP, Johnson GL, Tyler KL. Reovirus-induced apoptosis is mediated by TRAIL. J Virol. 2000; 74: 8135-9.

24. Rikhof B, van der Graaf WT, Meijer C, Le PT, Meersma GJ, de Jong S, Fletcher JA, Suurmeijer AJ. Abundant Fas expression by gastrointestinal stromal tumours may serve as a therapeutic target for MegaFasL. Br J Cancer. 2008; 99: 1600-6. https://doi.org/10.1038/sj.bjc.6604736.

25. Joensuu H, Roberts PJ, Sarlomo-Rikala M, Andersson LC, Tervahartiala P, Tuveson D, Silberman S, Capdeville R, Dimitrijevic S, Druker B, Demetri GD. Effect of the tyrosine kinase inhibitor STI571 in a patient with a metastatic gastrointestinal stromal tumor. N Engl J Med. 2001; 344: 1052-6. https://doi.org/10.1056/nejm200104053441404.

26. Blay JY, Bonvalot S, Casali P, Choi H, Debiec-Richter M, Dei Tos AP, Emile JF, Gronchi A, Hogendoorn PC, Joensuu $\mathrm{H}$, Le Cesne A, McClure J, Maurel J, et al. Consensus meeting for the management of gastrointestinal stromal tumors. Report of the GIST Consensus Conference of 20-21 March 2004, under the auspices of ESMO. Ann Oncol. 2005; 16: 566-78. https://doi.org/10.1093/annonc/mdi127.

27. Demetri GD, von Mehren M, Blanke CD, Van den Abbeele AD, Eisenberg B, Roberts PJ, Heinrich MC, Tuveson DA, Singer S, Janicek M, Fletcher JA, Silverman SG, Silberman SL, et al. Efficacy and safety of imatinib mesylate in advanced gastrointestinal stromal tumors. N Engl J Med. 2002; 347: 472-80. https://doi.org/10.1056/NEJMoa020461.

28. Blanke CD, Rankin C, Demetri GD, Ryan CW, von Mehren M, Benjamin RS, Raymond AK, Bramwell VH, Baker LH, Maki RG, Tanaka M, Hecht JR, Heinrich MC, et al. Phase III randomized, intergroup trial assessing imatinib mesylate at two dose levels in patients with unresectable or metastatic gastrointestinal stromal tumors expressing the kit receptor tyrosine kinase: S0033. J Clin Oncol. 2008; 26: 626-32. https://doi.org/10.1200/jco.2007.13.4452.

29. Cassier PA, Fumagalli E, Rutkowski P, Schoffski P, Van Glabbeke M, Debiec-Rychter M, Emile JF, Duffaud F, Martin-Broto J, Landi B, Adenis A, Bertucci F, Bompas $\mathrm{E}$, et al. Outcome of patients with platelet-derived growth factor receptor alpha-mutated gastrointestinal stromal tumors in the tyrosine kinase inhibitor era. Clin Cancer Res. 2012; 18: 4458-64. https://doi.org/10.1158/1078-0432. ccr-11-3025.

30. Nishida T, Blay JY, Hirota S, Kitagawa Y, Kang YK. The standard diagnosis, treatment, and follow-up of gastrointestinal stromal tumors based on guidelines. Gastric Cancer. 2016; 19: 3-14. https://doi.org/10.1007/ s10120-015-0526-8.

31. Duncan MR, Stanish SM, Cox DC. Differential sensitivity of normal and transformed human cells to reovirus infection. J Virol. 1978; 28: 444-9.

32. Hashiro G, Loh PC, Yau JT. The preferential cytotoxicity of reovirus for certain transformed cell lines. Arch Virol. 1977; 54: 307-15.

33. Strong JE, Lee PW. The v-erbB oncogene confers enhanced cellular susceptibility to reovirus infection. J Virol. 1996; 70: 612-6.

34. Strong JE, Coffey MC, Tang D, Sabinin P, Lee PW. The molecular basis of viral oncolysis: usurpation of the Ras signaling pathway by reovirus. EMBO J. 1998; 17: 335162. https://doi.org/10.1093/emboj/17.12.3351.

35. Kee D, Zalcberg JR. Current and emerging strategies for the management of imatinib-refractory advanced gastrointestinal stromal tumors. Ther Adv Med Oncol. 2012; 4: 255-70. https://doi.org/10.1177/1758834012450935. 
36. Yang J, Ikezoe T, Nishioka C, Takezaki Y, Hanazaki K, Taguchi T, Yokoyama A. Long-term exposure of gastrointestinal stromal tumor cells to sunitinib induces epigenetic silencing of the PTEN gene. Int J Cancer. 2012; 130: 959-66. https://doi.org/10.1002/ijc.26095.

37. Sako H, Fukuda K, Saikawa Y, Nakamura R, Takahashi T, Wada N, Kawakubo H, Takeuchi H, Ohmori T, Kitagawa Y. Antitumor effect of the tyrosine kinase inhibitor nilotinib on gastrointestinal stromal tumor (GIST) and imatinibresistant GIST cells. PLoS One. 2014; 9: e107613. https:// doi.org/10.1371/journal.pone.0107613.

38. Heinrich MC, Corless CL, Blanke CD, Demetri GD, Joensuu H, Roberts PJ, Eisenberg BL, von Mehren M, Fletcher CD, Sandau K, McDougall K, Ou WB, Chen $\mathrm{CJ}$, et al. Molecular correlates of imatinib resistance in gastrointestinal stromal tumors. J Clin Oncol. 2006; 24: 4764-74. https://doi.org/10.1200/jco.2006.06.2265.

39. Bauer S, Duensing A, Demetri GD, Fletcher JA. KIT oncogenic signaling mechanisms in imatinib-resistant gastrointestinal stromal tumor: PI3-kinase/AKT is a crucial survival pathway. Oncogene. 2007; 26: 7560-8. https://doi. org/10.1038/sj.onc.1210558.

40. Ashkenazi A, Dixit VM. Death receptors: signaling and modulation. Science. 1998; 281: 1305-8.

41. Clarke P, Meintzer SM, Spalding AC, Johnson GL, Tyler KL. Caspase 8-dependent sensitization of cancer cells to TRAIL-induced apoptosis following reovirus-infection. Oncogene. 2001; 20: 6910-9. https://doi.org/10.1038/ sj.onc. 1204842 .
42. Timmer T, de Vries EG, de Jong S. Fas receptor-mediated apoptosis: a clinical application? J Pathol. 2002; 196: 12534. https://doi.org/10.1002/path.1028.

43. Peter ME, Hadji A, Murmann AE, Brockway S, Putzbach W, Pattanayak A, Ceppi P. The role of CD95 and CD95 ligand in cancer. Cell Death Differ. 2015; 22: 549-59. https://doi.org/10.1038/cdd.2015.3.

44. Clarke P, Beckham JD, Leser JS, Hoyt CC, Tyler KL. Fasmediated apoptotic signaling in the mouse brain following reovirus infection. J Virol. 2009; 83: 6161-70. https://doi. org/10.1128/jvi.02488-08.

45. Taguchi T, Sonobe H, Toyonaga S, Yamasaki I, Shuin T, Takano A, Araki K, Akimaru K, Yuri K. Conventional and molecular cytogenetic characterization of a new human cell line, GIST-T1, established from gastrointestinal stromal tumor. Lab Invest. 2002; 82: 663-5.

46. Varghese F, Bukhari AB, Malhotra R, De A. IHC Profiler: an open source plugin for the quantitative evaluation and automated scoring of immunohistochemistry images of human tissue samples. PLoS One. 2014; 9: e96801. https:// doi.org/10.1371/journal.pone.0096801.

47. Kanda Y. Investigation of the freely available easy-touse software 'EZR' for medical statistics. Bone Marrow Transplant. 2013; 48: 452-8. https://doi.org/10.1038/ bmt.2012.244. 